\title{
Effects of eccentric exercise in pressure pain threshold in subjects with functional ankle equinus condition
}

\author{
David Rodriguez Sanz ${ }^{1}$ \\ (iD) Daniel Lopez-Lopez² \\ D Daniel Muñoz Garcia ${ }^{3}$ \\ (D) Alfredo Soriano Medrano 4 \\ (iD) Angel Morales Ponce 4 \\ (iD) Cesar Calvo Lobo \\ DIrene Sanz Corbalan ${ }^{6}$
}

http://dx.doi.org/10.1590/1806-9282.65.3.384

\section{SUMMARY}

Stretching exercises are widely used by the population before sporting activities. One of the most common technique is eccentric exercise. Here, we made a clinical examination of 98 subjects with equinus condition before activity and after 30 min of running (49 participants with previous eccentric exercise and 49 with no previously eccentric exercise). The clinical assessment of the Achilles tendon was based on the pressure pain threshold (PPT). We identified significant PPT changes between the previous eccentric stretching and the non-previous eccentric stretching group in the Achilles tendon evaluations. Based on our findings, we propose that subjects with equinus condition could use eccentric stretching in order to improve the Achilles tendon status.

KEYWORDS: Ankle. Foot. Sports. Equinus Deformity.

\section{INTRODUCTION}

Equinus is a clinical ankle condition that limits the dorsiflexion range of movement. Equinus could be explained as the "limitation of the ankle for dorsiflexion with the knee extended and/or flexed (excluding osseous-restriction)" ${ }^{1,2}$. Although Equinus is a non-symptomatic pathologic pattern, it may promote a clinical alteration in the Achilles tendon (AT) and triceps surae muscle. Equinus condition is deep- ly related to lower limb injuries (as anterior cruciate ligament rupture), hip pain, ankle sprain, asymmetric load patterns, and changes in muscle activity for the triceps surae ${ }^{3-6}$.

Equinus condition could promote a higher basal activation for triceps surae and hamstring muscles. This clinical condition has been investigated using force-pressure platforms ${ }^{7-10}$ and its relationships be-

DATE OF SUBMISSION: 13-Aug-2018

DATE OF ACCEPTANCE: 26-Aug-2018

Corresponding Author: David Rodriguez Sanz

Universidad Europea de Madrid. Faculty of Sport Sciences, Villaviciosa de Odón, Madrid, Spain

Physical Therapy \& Health Sciences Research Group

E-mail: davidrodriguezsanz@gmail.com 
tween muscle activity patterns have been studied by electromyography ${ }^{11-13}$. Equinus condition is deeply related to gait, posture ${ }^{9,10}$ and injuries. The activation of the triceps surae musculature could modify the mechanosensitivity of the Achilles tendon and promote other alterations ${ }^{14-17}$. Human posture is actively supported by the contraction of muscles as gluteus, hamstrings and triceps surae.

We aimed to assess with an algometer the PPT values for the Achilles tendon. The main aim of the study was to check PPT values between eccentric and non-eccentric stretching in subjects with Equinus before and after running exercise.

\section{METHODS}

This was an observational study; 98 healthy male subjects were recruited. A consecutive sampling method was used to select participants. A total of 49 subjects with eccentric stretching and 49 with non-eccentric stretching were recruited. All participants completed the study. The exclusion criteria were the presence of sprains, infection, bone alteration, musculoskeletal disorders, tendon injuries, low back and pelvic pain, scoliosis, and use of drugs in the week preceding the test.

The studied variable was PPT. The pain pressure threshold was measured with an algometer. Twenty eccentric stretching exercises were carried out before the activity. Subjects then ran for 30 minutes on a treadmill at a speed of $10 \mathrm{~km} / \mathrm{h}$, and the PPT assessment was repeated.

\section{Sample size calculation}

The sample size calculation was carried out by the difference between two independent groups with the $G^{*}$ Power statistic tool and based on the right-Achilles tendon PPT of a case-control pilot study with 2-groups [mean (SD)], $\mathrm{n}=10$ subjects with Equinus condition [1.60 (0.57) kg/cm2] and $\mathrm{n}=10$ subjects without Equinus condition $[1.98(0.57) \mathrm{kg} /$ $\mathrm{cm}]$. Indeed, 1 tail hypothesis, an effect size of 0.67 , an $\alpha$-error of 0.05, and a power of 0.95 were used for the sample size calculation. Therefore, a total sample size of 98 subjects, 49 for each group, was obtained.

\section{Ethical considerations}

The Ethics Committee of the HULP (Madrid, Spain; record number: CE 2828A) approved the study. All participants provided signed informed con- sent before the beginning of the study. The ethical standards for human experimentation of the Declaration of Helsinki and the Strengthening the Reporting of Observational Studies in Epidemiology (STROBE) guidelines were applied.

\section{Clinical exploration}

First, subjects lay in a supine position, and their Equinus condition was assessed with the knee extended/flexed. The range of movement was checked using a goniometer to evaluate the angle between the plantar line of the foot and the tibia bone axis. The PPT was checked using an algometer before and after activity. The Equinus assessment and PPT was carried out by the same Podiatry Doctor (D.R.S) in order to ensure the reliability of measurements.

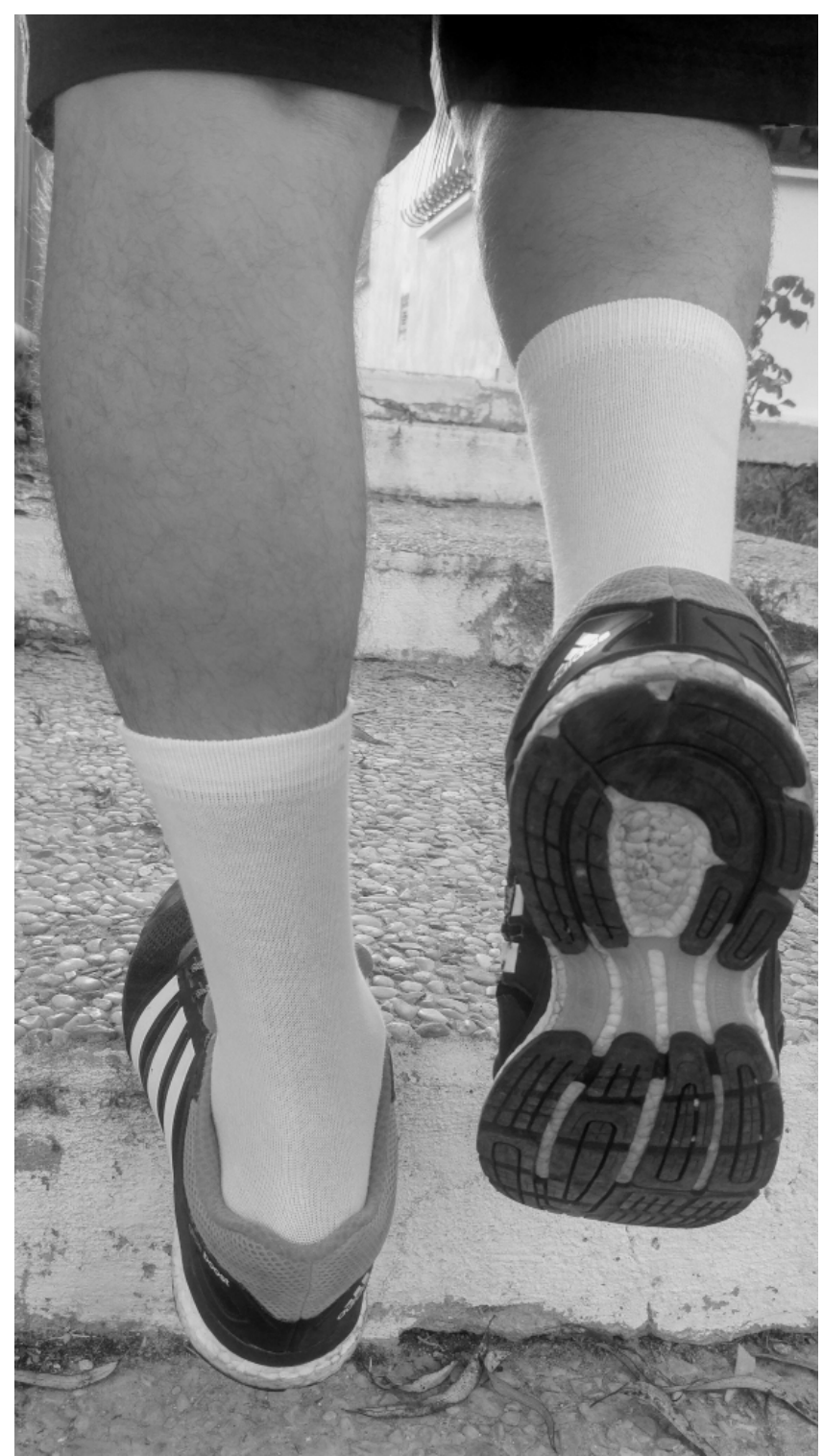

FIGURE 1 


\section{STATISTICAL ANALYSIS}

Statistical analyses were carried out with SPSS (version 22.0 for Windows, IBM SPSS Statistics for Windows, Armonk, NY, IBM Corp) with an $\alpha$ error of 0.05 (95\% confidence interval [CI]), with the desired power of $80 \%$ ( $\beta$ error of 0.2$)$.

The Kolmogorov-Smirnov test was used to assess data normality. All data were normally distributed, and the parametric statistical tests were selected. The mean and standard deviation of the temperature data were obtained for the selected lower limb muscles Achilles tendon.

Unpaired sample Student's t-test were performed to test for statistically significant differences in height, weight, body mass index, and age between the two groups. Paired Student's t-tests were performed to determine differences between the groups (Eccentric and non-eccentric stretching) as well as between sessions (before and after running).

\section{RESULTS}

We found no statistically significant differences between the eccentric and non-eccentric groups for participant height, weight, age, or body mass index (Table 1).

TABLE 1. PARTICIPANT CHARACTERISTICS $(N=49$ ECCENTRIC STRETCHING AND 49 NON-ECCENTRIC STRETCHING)

\begin{tabular}{l|l|l} 
& \multicolumn{1}{l}{$\begin{array}{l}\text { Eccentric exercise } \\
\text { group }\end{array}$} & $\begin{array}{l}\text { Non-eccentric } \\
\text { group }\end{array}$ \\
\hline Age $(\text { years })^{\star}$ & $34.56 \pm 3.7$ & $36.2 \pm 2.4$ \\
\hline Height $(\mathrm{cm})^{\star}$ & $174.5 \pm 5.3$ & $168.1 \pm 4.9$ \\
\hline Weight $(\mathrm{kg})^{\star}$ & $71.8 \pm 2.1$ & $70.2 \pm 1.9$ \\
\hline Body mass index $^{*}$ & $21.1 \pm 1.2$ & $20.8 \pm 1.4$
\end{tabular}

* No statistically significant difference between groups $(p \geq 0.05)$.

We found significant differences for pressure pain threshold in the Achilles tendon between both groups (eccentric and non-eccentric stretching exercises) after the activity (Table 2).

\section{DISCUSSION}

Here, we identified that the PPT values were also lower for the non-eccentric stretching group vs. the eccentric stretching participants.

The triceps surae requires stronger activation in subjects with Equinus condition, therefore, might
TABLE 2. PRESSURE PAIN THRESHOLD ASSESSMENT

\begin{tabular}{l|l|l} 
& $\begin{array}{l}\text { PPT Before } \\
\text { Running }\end{array}$ & \multicolumn{1}{l}{$\begin{array}{l}\text { PPT After } \\
\text { Running }\end{array}$} \\
\hline & Mean (SD) & \multicolumn{1}{l}{ Mean (SD) } \\
\hline Eccentric stretching & $2.7(0.22)$ & $3.5(0.33)$ \\
\hline Non-eccentric stretching & $2.5(0.14)$ & $2.8(0.13)$ \\
\hline$p$-value & $0.17^{*}$ & $0.01 \dagger$ \\
\hline
\end{tabular}

${ }^{\star}$ No statistically significant difference between groups before running. † Statistically significant difference between groups before running

be affected early by pain or fatigue, thus explaining why we observed an increase in PPT values for the eccentric stretching participants compared with the non-eccentric stretching participants. In the assessment before running, we did not find any significant differences in the PPT values. The running exercise may serve as a stimulus to increase PPT values in muscles and consequently differences between groups.

Eccentric stretching exercise may assist triceps surae extensibility during loading and running and promote venous return. Biomechanically, the maximum ankle dorsiflexion during the stance-phase of a normal gait occurs before heel lift with the knee completed extended. ${ }^{1}$ The most deeply known range of movement values for ankle dorsiflexion in the reviewed literature for static evaluation is the minimum dorsiflexion movement of the ankle for normal gait, which is $10^{\circ}$ of motion..$^{3,18-23}$

Further studies are necessary to improve our knowledge of muscle condition and establish the clinical relevance of the association between PPT in non-equinus subjects ${ }^{25,26}$. Based on our findings, we propose that eccentric stretching exercise be recommended for runners with GSE condition.

\section{CONCLUSIONS}

The eccentric stretching group showed a higher PPT-value for the Achilles tendon after exercise than the non-eccentric group. Therefore, an algometer that measures pain pressure threshold could be promoted as a screening tool for prevention or therapeutic actions. Based on our findings, we propose that eccentric exercise be recommended for subjects with GSE condition

Financial disclosure

None 


\section{RESUMO}

Exercícios de alongamento são amplamente utilizados pela população antes da atividade esportiva. Uma das técnicas mais comuns é o exercício excêntrico. Aqui, fizemos um exame clínico de 98 indivíduos com condição de pé equino antes da atividade e após 30 minutos de corrida (49 corredores com exercício excêntrico anterior e 49 sem exercício excêntrico anterior). A avaliação clínica do tendão de Aquiles foi baseada no limiar de dor à pressão (PPT). Identificamos modificações significativas no PPT entre alongamentos prévios excêntricos e nenhum exercício anterior excêntrico de alongamento para as avaliações do tendão de Aquiles. Com base em nossos achados, propomos que sujeitos com condição de pé equino poderiam fazer alongamentos com exercícios excêntricos para melhorar o status do tendão de Aquiles.

PalaVRas-Chave: Tornozelo. Pé. Esportes. Pé equino.

\section{REFERENCES}

1. DiGiovanni CW, Kuo R, Tejwani N, Price R, Hansen ST Jr, Cziernecki J, et al. Isolated gastrocnemius tightness. J Bone Joint Surg Am. 2002;84$A(6): 962-70$.

2. Downey MS, Banks AS. Gastrocnemius recession in the treatment of nonspastic ankle equinus. A retrospective study. I Am Podiatr Med Assoc. 1989;79(4):159-74.

3. Lamm BM, Paley D, Herzenberg JE. Gastrocnemius soleus recession: a simpler, more limited approach. J Am Podiatr Med Assoc. 2005;95(1):1825.

4. Silfverskiold N. Reduction of the uncrossed two-joints muscles of the leg to one-joint muscles in spastic conditions. Acta Chir Scand. 1924;56:31530 .

5. Downey MS. "Ankle equinus". In: McGlamry ED, Banks AS, Downey MS, eds. Comprehensive textbook of foot surgery. $2^{\text {nd }}$ ed. vol. 1. Baltimore: Williams \& Wilkins; 1992. p.687.

6. Root ML, Orien WP, Weed JH. Normal and abnormal function of the foot. Los Angeles: Clinical Biomechanics Corp; 1977.

7. Blustein SM, D'Amico JC. Limb length discrepancy. Identification, clinical significance, and management. J Am Podiatr Med Assoc. 1985;75(4):2006.

8. Mahar RK, Kirby RL, MacLeod DA. Simulated leg-length discrepancy: its effect on mean center-of-pressure position and postural sway. Arch Phys Med Rehabil. 1985;66(12):822-4.

9. Bhave A, Paley D, Herzenberg JE. Improvement in gait parameters after lengthening for the treatment of limb-length discrepancy. J Bone Joint Surg Am. 1999;81(4):529-34.

10. Blake RL, Ferguson H. Limb length discrepancies. J Am Podiatr Med Assoc. 1992;82(1):33-8.

11. Vink $P$, Huson $A$. Lumbar back muscle activity during walking with a leg inequality Acta Morphol Neerl Scand. 1987;25(4):261-71.

12. Gurney B, Mermier C, Robergs R, Gibson A, Rivero D. Effects of limblength discrepancy on gait economy and lower-extremity muscle activity in older adults. J Bone Joint Surg Am. 2001;83-A(6):907-15.

13. Balestra G, Frassinelli S, Knaflitz M, Molinari F. Time-frequency analysis of surface myoelectric signals during athletic movement. IEEE Eng Med Biol Mag. 2001;20(6):106-15.
14. Merla A, lodice P, Tangherlini A, De Michele G, Di Romualdo S, Saggini $R$, et al. Monitoring skin temperature in trained and untrained subjects throughout thermal video. Conf Proc IEEE Eng Med Biol Soc. 2005;2:1684-6

15. Zontak A, Sideman S, Verbitsky O, Beyar R. Dynamic thermography: analysis of hand temperature during exercise. Ann Biomed Eng. 1998;26(6):988-93.

16. Ammer K, Formenti D. Editorial: Does the type of skin temperature distribution matter? Thermol Internat. 2016;26(2):51-4.

17. Formenti D, Ludwig N, Rossi A, Trecoci A, Alberti G, Gargano M, et al. Skin temperature evaluation by infrared thermography: comparison of two image analysis methods during the nonsteady state induced by physical exercise. Infrared Physics and Technology. 2017;81:32-40.

18. McGlamry ED, Kitting RW. Aquinus foot: an analysis of the etiology, pathology and treatment techniques. J Am Podiatry Assoc. 1973;63(5):16584.

19. Knutzen KM, Price A. Lower extremity static and dynamic relationships with rearfoot motion in gait. J Am Podiatr Med Assoc. 1994;84(4):171-80.

20. Nuber GW. Biomechanics of the foot and ankle during gait. Clin Sports Med. 1988;7(1):1.

21. Lavery LA, Armstrong DA, Boulton AJM; Diabetex Research Group. Ankle equines deformity and its relationship to high plantar pressure in a large population with diabetes mellitus. J Am Podiatr Med Assoc. 2002;92(9):479-82.

22. Wrobel JS, Connolly JE, Beach ML. Associations between static and functional measures of joint function in the foot and ankle. J Am Podiatr Med Assoc. 2004;94(6):535-41.

23. Winter DA. Kinematic and kinetic patterns in human gait: variability and compensating effects. Human Mov Sci. 1984;3:51-76.

24. Brodersen $A$, Pedersen $B$, Reimers J. Foot deformities and relation to the length of leg muscles in Danish children aged 3-17 years. Ugeskr Laeger. 1993;155(48):3914-6.

25. Abate M, Carlo LD, Romualdo SD, lonta S, Ferretti A, Romani GL, et al. Postural adjustment in experimental leg length difference evaluated by means of thermal infrared imaging. Physiol Meas. 2010;31(1):35-43.

26. Bernardo WM, Meleiro SAS, Mendes VTA, Kaleka CC, Cury RPL. Update of treatment of isolated lesions of the posterior cruciate ligament. Rev Assoc Med Bras. 2015;61(2):100. 